\title{
Recognition of Two New Species of Intestinal Spirochetes: Serpulina intermedia sp. nov. and Serpulina murdochii sp. nov.

\author{
T. B. STANTON, ${ }^{1 *}$ E. FOURNIÉ-AMAZOUZ, ${ }^{2}$ D. POSTIC, ${ }^{2}$ D. J. TROTT, ${ }^{3}$ \\ P. A. D. GRIMONT ${ }^{4}$ G. BARANTON, ${ }^{2}$ D. J. HAMPSON, ${ }^{3}$ \\ AND I. SAINT GIRONS ${ }^{2}$ \\ Enteric Diseases and Food Safety Research Unit, National Animal Disease Center, \\ Agricultural Research Service, United States Department of Agriculture, Ames, \\ Iowa 50010 ${ }^{1}$; Unité Bactériologie Moléculaire et Médicale, ${ }^{2}$ and Unité des \\ Entérobactéries, ${ }^{4}$ Institut Pasteur, 75724 Paris cedex 15, France; \\ and School of Veterinary Studies, Murdoch University, \\ Murdoch, Western Australia 6150, Australia ${ }^{3}$
}

\begin{abstract}
On the basis of DNA-DNA hybridization data, nine intestinal spirochete strains were grouped into five genospecies. Three of these genospecies were previously recognized Serpulina species, Serpulina hyodysenteriae (type strain, B78), Serpulina innocens (type strain, B256), and Serpulina pilosicoli (type strain, P43/6/78; previously "Anguillina coli"). The other two genospecies were found to be new Serpulina species, for which we propose the names Serpulina intermedia sp. nov. (with type strain PWS/A) and Serpulina murdochii sp. nov. (with type strain 56-150). S. intermedia and $S$. murdochii cells had a typical spirochete ultrastructure with 22 to 28 periplasmic flagella per cell. Various soluble sugars were growth substrates for $S$. intermedia and $S$. murdochii. During growth in basal heart infusion broth supplemented with fetal calf serum beneath an $\mathrm{O}_{2}-\mathrm{N}_{2}$ (1:99) atmosphere, cells of these new species consumed oxygen and glucose and produced $\mathrm{H}_{2}, \mathrm{CO}_{2}$, acetate, butyrate, and ethanol. The $G+C$ content of the DNA of $S$. murdochii $56-150^{T}$ was 27 mol\%, and the $G+C$ content of the DNA of $S$. intermedia PWS/A $\mathrm{A}^{\mathrm{T}}$ was $25 \mathrm{~mol} \%$. In addition, a restriction fragment length polymorphism-PCR assay for the detection of intestinal spirochetes was developed. The assay was based on generation and restriction endonuclease analysis (with HinfI, TaqI, Sau3A, and MboII) of a 558-bp amplicon of ribosomal DNA (rDNA) encoding 16S rRNA. The PCR amplification was specific for Serpulina species and Brachyspira aalborgi. Four restriction digest patterns were found for the five Serpulina species. HinfI restriction differentiated $S$. murdochii and $S$. innocens from the other species. Sau3A and TaqI restrictions gave unique fragment patterns for $S$. murdochii and $S$. pilosicoli, respectively. $S$. hyodysenteriae and $S$. intermedia DNAs gave the same fragment pattern regardless of the enzyme tested. $B$. aalborgi was differentiated from the Serpulina species by MboII digestion of the $16 \mathrm{~S}$ rDNA amplicon.
\end{abstract}

Swine dysentery (13) and porcine intestinal spirochetosis $(36,40)$ can be differentiated by their clinical signs. Swine dysentery is a severe, mucohemorrhagic diarrheal disease that sometimes leads to death. Porcine intestinal spirochetosis is a mucus-containing, nonbloody diarrheal disease which leads to a poor growth rate in young pigs. The etiological agents of these two diseases are separate species of intestinal spirochetes belonging to the genus Serpulina, the strongly hemolytic organism Serpulina hyodysenteriae (13) and the weakly hemolytic organism Serpulina pilosicoli (formerly called "Anguillina coli") (40), respectively. Some human intestinal spirochetes $(1,18$, $29)$ have been identified as $S$. pilosicoli $(25,41)$. Other previously characterized spirochetes found in the gastrointestinal tracts and feces of animals and humans include two nonpathogenic species from swine, Serpulina innocens (31) and Treponema succinifaciens (5), and a human spirochete, Brachyspira aalborgi, which is believed to be a commensal (14). There undoubtedly are other intestinal spirochete species that either have not been cultivated or have not been characterized.

An analysis of a large collection of intestinal spirochete

* Corresponding author. Mailing address: Enteric Diseases and Food Safety Research Unit, National Animal Disease Center, USDAARS, P.O. Box 70, Ames, IA 50010. Phone: (515) 239-8495. Fax: (515) 239-8458. E-mail: tstanton@nadc.ars.usda.gov. strains by multilocus enzyme electrophoresis (MEE) revealed great diversity among these spirochetes and led to the identification of five MEE groups (20), the three Serpulina spp. mentioned above and two other groups assigned the provisional species names "Serpulina intermedius" and "Serpulina murdochii" $(19,20)$. However, the new groups established by MEE analysis required further genetic and phenotypic analysis before they could be confirmed as new species.

More recently, MEE analysis established two additional spirochete groups (35), and comparisons of $16 \mathrm{~S}$ ribosomal DNA (rDNA) sequences of intestinal spirochetes belonging to the seven MEE groups demonstrated that they are closely related to one another $(26,35)$. The highly conserved $16 \mathrm{~S}$ rDNA sequences of these intestinal spirochetes led to a recommendation that alternative techniques, such as DNA-DNA relative reassociation, should be used to define Serpulina species (35).

The goals of the present study were to clearly define the proposed new species by using a recognized taxonomic tool, DNA-DNA reassociation (42), to provide descriptions of phenotypic characteristics of the new species, and to develop a discriminatory assay for Serpulina spp. by using a restriction fragment length polymorphism (RFLP)-PCR assay based on rDNA encoding the $16 \mathrm{~S}$ rRNA. Based on our results, we propose the following two new species in the genus Serpulina: Serpulina intermedia sp. nov. and Serpulina murdochii sp. nov. 
TABLE 1. Strains of intestinal spirochetes used in this study

\begin{tabular}{|c|c|c|c|c|c|c|}
\hline Taxon & Strain & $\begin{array}{l}\text { 16S rRNA } \\
\text { sequence acces- } \\
\text { sion no. }{ }^{a}\end{array}$ & $\begin{array}{c}\text { MEE } \\
\text { group }^{b}\end{array}$ & Origin & Pathogenesis & $\begin{array}{l}\text { Refer- } \\
\text { ence(s) }\end{array}$ \\
\hline S. hyodysenteriae & $\mathrm{B} 78^{\mathrm{T}}\left(=\operatorname{ATCC} 27164^{\mathrm{T}}\right)$ & M57743, U14930 & I & Swine dysentery & Pathogenic for swine & 13,33 \\
\hline S. hyodysenteriae & $\mathrm{R}-1$ & U23035 & I & Rhea colitis & Not pathogenic for swine & 17,27 \\
\hline S. innocens & $\mathrm{B} 256^{\mathrm{T}}\left(=\right.$ ATCC $\left.29796^{\mathrm{T}}\right)$ & M57744, U14920 & III & Swine & Not pathogenic for swine & 33 \\
\hline S. pilosicoli & $\mathrm{P} 43 / 6 / 78^{\mathrm{T}}\left(=\right.$ ATCC $\left.51139^{\mathrm{T}}\right)$ & U23032, U14927 & VI & Swine colitis & Pathogenic for swine & 36,40 \\
\hline S. pilosicoli & WES-B & U23034 & VI & Human diarrhea & $\begin{array}{l}\text { Pathogenic for 1-day-old chickens } \\
\text { and for swine }\end{array}$ & 19,37 \\
\hline S. intermedia sp. nov. & PWS $/ A^{\mathrm{T}}\left(=\operatorname{ATCC} 51140^{\mathrm{T}}\right)$ & $\mathrm{U} 23033$ & II & Swine diarrhea & Not pathogenic for swine & 15,21 \\
\hline S. intermedia sp. nov. & 2818.5 & None & II & Swine & Not tested & 20 \\
\hline S. murdochii sp. nov. & $56-150^{\mathrm{T}}\left(=\right.$ ATCC $\left.51254^{\mathrm{T}}\right)$ & None & V & Swine & Not tested & 20 \\
\hline S. murdochii sp. nov. & $155-20(=$ ATCC 51284$)$ & U22838 & $\mathrm{V}$ & Swine & Not tested & 20 \\
\hline B. aalborgi & $513 \mathrm{~A}^{\mathrm{T}}\left(=\right.$ ATCC $\left.43994^{\mathrm{T}}\right)$ & $\mathrm{Z} 22781$ & VII & Human colitis & Not tested & 14 \\
\hline
\end{tabular}

${ }^{a}$ GenBank accession numbers for $16 \mathrm{~S}$ rDNA sequences.

${ }^{b}$ MEE groups as designated by Stanton et al. (35).

\section{MATERIALS AND METHODS}

Organisms and growth conditions. The intestinal spirochetes were routinely cultivated in TGY anaerobic medium (Diagnostic Pasteur) or in brain heart infusion broth containing $10 \%$ calf serum (BHIS broth) (34) at 37 to $39^{\circ} \mathrm{C}$. The organisms used included strains listed in Table 1 , as well as spirochetes isolated from the blood of humans. Human strains PE90, 81/80, 28/94, RA87, 128/90, and $382 / 91$ have been described and identified as $S$. pilosicoli previously $(9,39)$. The following three additional strains were identified as $S$. pilosicoli in this study: strain DOA95, isolated from a 43-year-old human immunodeficiency virus-positive man who is still living and previously had colonic spirochetosis; strain VIR94, originally isolated from a 65-year-old man who subsequently died from hepatoma; and strain FE96, isolated from a 69-year-old man who was hospitalized in a reanimation unit for hypothermia, coma, and shock and who died 2 weeks later. Spirochete cell numbers were determined by using a Petroff-Hausser counting chamber.

Phenotypic characteristics. The methods used to determine population doubling times, growth substrates, API-ZYM profiles, end products, hippuratehydrolyzing abilities, and other culture characteristics were similar to those used in studies of $S$. pilosicoli (40) and $S$. hyodysenteriae (34). For growth substrate determinations, $S$. intermedia and $S$. murdochii cells were cultured beneath an $\mathrm{N}_{2}-\mathrm{O}_{2}$ (99:1) atmosphere in HS broth, which was basal heart infusion broth (34) supplemented with fetal calf serum (at final concentrations of 7 and $10 \%$ [vol/ vol], respectively). The conditions used for electron microscopy of negatively stained bacterial cells have been described previously (40). Periplasmic flagellar numbers and cell dimensions were determined by using at least 20 cells.

DNA-DNA reassociation. Serpulina DNA was extracted and purified by a modified method of Marmur as described previously (33). DNA relatedness was determined by the $S 1$ nuclease method (4) by using a previously described procedure (10). Due to the low $\mathrm{G}+\mathrm{C}$ content of Serpulina DNA, a reassociation temperature of $55^{\circ} \mathrm{C}$ was used. The temperature at which $50 \%$ of the reassociated DNA was hydrolyzed by $\mathrm{S} 1$ nuclease $\left(T_{m}\right)$ was determined. Differences between the $T_{m}$ of the homoduplex (in the homologous reaction) and the $T_{m}$ values of the heteroduplexes (in the heterologous reactions) $\left(\Delta T_{m}\right.$ values) were determined in order to estimate DNA divergence.

DNA base composition. The guanine-plus-cytosine $(\mathrm{G}+\mathrm{C})$ contents of DNAs from $S$. murdochii $56-150^{\mathrm{T}}$ and $S$. intermedia $\mathrm{PWS} / \mathrm{A}^{\mathrm{T}}$ were determined by thermal denaturation by using DNA from each spirochete at a final concentration of $50 \mu \mathrm{g} / \mathrm{ml}$ in $0.1 \times \mathrm{SSC}(1 \times \mathrm{SSC}$ is $0.15 \mathrm{M} \mathrm{NaCl}$ plus $0.015 \mathrm{M}$ sodium citrate $)$. The methods used to prepare DNA and buffers, to determine $T_{m}$ values, and to calculate $\mathrm{G}+\mathrm{C}$ contents have been described previously $(22,40)$. DNAs from $S$. hyodysenteriae $\mathrm{B} 78^{\mathrm{T}}(\mathrm{G}+\mathrm{C}$ content, $25 \pm 1 \mathrm{~mol} \%)$ and Escherichia coli $\mathrm{XL}-1$ $(50 \pm 1 \mathrm{~mol} \%)$ were used as controls.

Enzymatic amplification and detection of PCR products. The cultured intestinal spirochetes listed in Table 1 plus the human blood isolates mentioned above were tested by PCR. Bacterial cells (approximately $10^{9}$ ) were harvested by centrifugation, washed twice with phosphate-buffered saline (28), resuspended in water, and heated twice at $100^{\circ} \mathrm{C}$ for $5 \mathrm{~min}$, followed by cooling on ice for $5 \mathrm{~min}$. The following two oligonucleotide primers were used: SER1 (5'-GGA-AAC GCC TCG GAT ACT GT- $3^{\prime}$ ) and SER2 (5'-CCT TCC TCC TAC TTG AAC GTA- $3^{\prime}$ ).

Oligonucleotides SER1 and SER2 correspond to nucleotides 720 to 733 and 1372 to 1352 in the primary structure of the E. coli $r m B$ operon corresponding to the $r s$ (16S rRNA) gene, respectively (3), or to nucleotides 599 to 618 and 1153 to 1133 of the $r s$ (16S rRNA) gene of $S$. hyodysenteriae (GenBank accession no. M57743), respectively.

Each DNA amplification mixture $(50 \mu \mathrm{l})$ consisted of $50 \mathrm{mM} \mathrm{KCl}, 10 \mathrm{mM}$ Tris hydrochloride ( $\mathrm{pH} 8.4$ ), $1.5 \mathrm{mM} \mathrm{MgCl}, 1 \mathrm{mg}$ of gelatin per ml, each oligonucleotide primer at a concentration of $1 \mu \mathrm{M}, 200 \mathrm{mM}$ dATP, $200 \mathrm{mM}$ dTTP, 200 $\mathrm{mM}$ dCTP, and $200 \mathrm{mM}$ dGTP. One unit of Taq DNA polymerase (PerkinElmer, Branchburg, N.J.) was used. A DNA sample corresponding to $5 \times 10^{7}$ cells was then added, and the reaction mixture was overlaid with $50 \mu \mathrm{l}$ of mineral oil (Sigma). The PCR was performed with an Omnigene thermal cycler (Hybaid Ltd., Middlesex, United Kingdom). Twenty-five cycles consisting of $30 \mathrm{~s}$ of denaturation at $94^{\circ} \mathrm{C}, 45 \mathrm{~s}$ of annealing at $57^{\circ} \mathrm{C}$, and $30 \mathrm{~s}$ of extension at $72^{\circ} \mathrm{C}$ were performed, and this was followed by an additional $10 \mathrm{~min}$ at $72^{\circ} \mathrm{C}$. The amplification products $(10 \mu \mathrm{l})$ were separated by electrophoresis in a $5 \%$ NuSieve (3:1) gel (FMC Bioproducts, Rockland, Maine) by using $1 \times$ TBE buffer (28), stained with ethidium bromide, illuminated by UV light, and analyzed. HinfI, TaqI, Sau3A, and MboII were used according to the instructions of the supplier (New England Biolabs, Beverly, Mass).

To determine the specificity of the oligonucleotide primers for Serpulina species, DNA preparations from the following pathogenic, related, or intestinal bacteria were tested under the same PCR conditions: Borrelia burgdorferi, Borrelia hermsii, Treponema denticola, Treponema pallidum, Leptospira interrogans, Spirochaeta aurantia, E. coli, Shigella flexneri, Salmonella enteritidis, Proteus mirabilis, Klebsiella pneumoniae, Streptococcus group D, Staphylococcus aureus, and Mycobacterium tuberculosis.

\section{RESULTS}

DNA relatedness and DNA analysis. The levels of DNA relatedness of nine strains of spirochetes are shown in Table 2. According to the criteria currently used to delineate genospecies (42), the differences in DNA relatedness and especially $\Delta T_{m}$ values are significant enough to define the following five species: $S$. hyodysenteriae, $S$. innocens, $S$. pilosicoli, $S$. murdochii sp. nov., and $S$. intermedia sp. nov. Within each of these species, the levels of DNA relatedness to the reference strains

TABLE 2. Levels of relative reassociation of $S$. hyodysenteriae, $S$. innocens, $S$. pilosicoli, S. intermedia, and S. murdochii DNAs

\begin{tabular}{|c|c|c|c|c|c|}
\hline \multirow{2}{*}{$\begin{array}{c}\text { Source of } \\
\text { unlabeled DNA }\end{array}$} & \multicolumn{5}{|c|}{$\begin{array}{c}\% \text { Relative reassociation with } \\
\text { labeled DNA from: }\end{array}$} \\
\hline & $\mathrm{B} 78^{\mathrm{T}}$ & $\mathrm{B} 256^{\mathrm{T}}$ & WES-B & $\mathrm{PWS} / \mathrm{A}^{\mathrm{T}}$ & $56-150^{\mathrm{T}}$ \\
\hline S. hyodysenteriae $\mathrm{B} 78^{\mathrm{T}}$ & 100 & & 25 & $57(7)^{a}$ & 27 \\
\hline S. hyodysenteriae R1 & $98(2)$ & $39(14)$ & & $63(7)$ & $34(>15)$ \\
\hline S. innocens $\mathrm{B} 256^{\mathrm{T}}$ & 29 & 100 & 22 & $45(12)$ & $66(7)$ \\
\hline S. pilosicoli $\mathrm{P} 43 / 6 / 78^{\mathrm{T}}$ & 21 & 23 & 78 & 28 & 22 \\
\hline S. pilosicoli WES-B & 28 & 29 & 100 & 26 & 28 \\
\hline S. intermedia $\mathrm{PWS} / \mathrm{A}^{\mathrm{T}}$ & $68(8)$ & 44 & 30 & 100 & 24 \\
\hline S. intermedia 2818.5 & $68(8)$ & 48 & & $80(4)$ & 40 \\
\hline S. murdochii $56-150^{\mathbf{T}}$ & 37 & $64(5)$ & & $37(15)$ & 100 \\
\hline S. murdochii $155-20$ & $28(13)$ & $64(5)$ & 29 & 45 & 79 (3) \\
\hline
\end{tabular}

${ }^{a}$ The values in parentheses are $\Delta T_{m}$ values (in degrees Celsius). 
TABLE 3. Growth substrates for $S$. murdochii $56-150^{\mathrm{T}}$ and $S$. intermedia $\mathrm{PWS} / \mathrm{A}^{\mathrm{T}}$

\begin{tabular}{lcc}
\hline \multirow{2}{*}{ Compound tested } & \multicolumn{2}{c}{ Growth response of $^{b}:$} \\
\cline { 2 - 3 } & S. murdochii $56-150^{\mathrm{T}}$ & S. intermedia PWS/A \\
\hline None & 0.6 & 0.6 \\
D-Glucose & 1.5 & 1.4 \\
D-Fructose & 1.0 & 1.4 \\
Sucrose & 1.1 & 1.5 \\
N-Acetyl-D-glucosamine & 1.4 & 1.8 \\
Pyruvate & 0.85 & 1.1 \\
L-Fucose & 0.9 & 1.1 \\
D-Cellobiose & 1.4 & - \\
D-Trehalose & 1.0 & 1.6 \\
D-Galactose & - & 1.1 \\
Maltose & 0.9 & 1.3 \\
D-Mannose & 0.9 & - \\
Lactose & 0.9 & -
\end{tabular}

${ }^{a}$ Substrates that did not support detectable growth of either strain included D-fucose, D-glucosamine, D-ribose, D-raffinose, D-rhamnose, and D-xylose.

${ }^{b}$ _, no detectable growth above the background level in medium without added substrate. The values are the maximum culture optical densities at $620 \mathrm{~nm}$ obtained in HS broth containing the substrates. The serum concentrations in HS broth for optimum growth of $S$. intermedia $\mathrm{PWS} / \mathrm{A}^{\mathrm{T}}$ and $S$. murdochii 56-150 were 7 and $10 \%$, respectively.

ranged from 78 to $100 \%$, with $\Delta T_{m}$ values of less than $4^{\circ} \mathrm{C}$. Between species, the levels of DNA relatedness to heterologous reference strains ranged from 21 to $68 \%$, with $\Delta T_{m}$ values of more than $5^{\circ} \mathrm{C}$. The DNA homology results indicate that rhea spirochete strain R-1 is an $S$. hyodysenteriae strain and that human spirochete strain WES-B is a strain of $S$. pilosicoli, which is consistent with the identification of these strains based on MEE analysis (35).

As determined by the thermal denaturation method, the $\mathrm{G}+\mathrm{C}$ content of the DNA of $S$. intermedia PWS $/ \mathrm{A}^{\mathrm{T}}$ was 25 $\mathrm{mol} \%$ and the $\mathrm{G}+\mathrm{C}$ content of the DNA of $S$. murdochii $56-150^{\mathrm{T}}$ was $27 \mathrm{~mol} \%$. Control DNAs of $S$. hyodysenteriae $\mathrm{B} 78^{\mathrm{T}}$ and $E$. coli XL-1 had $\mathrm{G}+\mathrm{C}$ contents of 24.2 and $50.8 \mathrm{~mol} \%$, respectively.

Cell morphology. Cells of $S$. intermedia $\mathrm{PWS} / \mathrm{A}^{\mathrm{T}}$ were 7.5 to 10 by 0.35 to $0.45 \mu \mathrm{m}$, and each cell had 24 to 28 flagella (12 to 14 flagella inserted at each end). Cells of $S$. murdochii $56-150^{\mathrm{T}}$ were 5 to 8 by 0.35 to $0.4 \mu \mathrm{m}$, and each cell had 22 to 26 flagella (11 to 13 inserted at each end). S. hyodysenteriae $\mathrm{B} 78^{\mathrm{T}}$ cells had 24 to 28 flagella per cell $(12$ to 14 inserted at each end) and average dimensions of 6 to 8.5 by 0.35 to $0.4 \mu \mathrm{m}$. Although these flagellar numbers for $S$. hyodysenteriae cells are higher than the 16 to 24 flagella per cell reported previously for this pathogenic spirochete (30), we did not observe fewer than 22 flagella per cell for strain $\mathrm{B} 78^{\mathrm{T}}$ cells and for cells of other $S$. hyodysenteriae strains under our culture conditions. It was not possible to distinguish cells of $S$. hyodysenteriae $\mathrm{B}^{7} 8^{\mathrm{T}}, S$. intermedia PWS $/ \mathrm{A}^{\mathrm{T}}$, and $S$. murdochii $56-150^{\mathrm{T}}$ based on cell dimensions, cell morphology, and numbers of flagella. $S$. pilosicoli cells generally are shorter (length, 5.3 to $7.3 \mu \mathrm{m}$ ) and thinner (width, 0.25 to $0.3 \mu \mathrm{m}$ ) than the cells of the other Serpulina species and have fewer flagella (8 to 10 flagella per cell) (40). Brachyspira aalborgii cells are 2 to $6 \mu \mathrm{m}$ long and have eight flagella per cell (14).

Cultural characteristics. In BHIS broth under an $\mathrm{N}_{2}-\mathrm{O}_{2}$ (99:1) atmosphere, $S$. hyodysenteriae, $S$. murdochii, and $S$. intermedia had optimum growth temperatures (shortest population doubling times and highest final population densities) of 39 to $42^{\circ} \mathrm{C}$. In BHIS broth at $39^{\circ} \mathrm{C}$, the population doubling times of $S$. hyodysenteriae $\mathrm{B}^{\mathrm{T}}$, S. murdochii $56-150^{\mathrm{T}}$, and
$S$. intermedia $\mathrm{PWS} / \mathrm{A}^{\mathrm{T}}$ were 2 to $4 \mathrm{~h}$, and the final population densities were $0.5 \times 10^{9}$ to $2.0 \times 10^{9}$ cells $/ \mathrm{ml}$. The spirochetes did not grow at 32 or $47^{\circ} \mathrm{C}$. Cells of both new species used soluble sugars as carbon and energy sources during growth in HS broth (Table 3). The final population densities in HS broth were two- to fivefold lower than the final population densities in BHIS broth. During growth on glucose in HS broth beneath a culture atmosphere that initially contained $1 \% \mathrm{O}_{2}$, cells of $S$. murdochii $56-150^{\mathrm{T}}$ and $S$. intermedia $\mathrm{PWS} / \mathrm{A}^{\mathrm{T}}$ consumed the $\mathrm{O}_{2}$ and yielded $\mathrm{H}_{2}, \mathrm{CO}_{2}$, acetate, butyrate, and ethanol (Table 4 ). Hydrogen was produced in greater amounts than $\mathrm{CO}_{2}$. In separate studies, the same products were detected with $S$. murdochii 155-20 and S. intermedia 2818.5, except that strain 2818.5 cultures did not produce detectable levels of ethanol. Additional phenotypic characteristics of $S$. intermedia, $S$. murdochii, and other Serpulina species are given in Table 5.

Differentiation of Serpulina species by RFLP-PCR analysis. Two primers were used to amplify DNAs from Serpulina strains. The first primer, SER1, was within a probe that hybridized to a region of the rrs (16S rRNA) gene and that has been used to differentiate $S$. hyodysenteriae from $S$. innocens (16). The second primer was chosen after we analyzed sequences of the rDNA encoding the 16S rRNA of strains of intestinal spirochetes in databases. The specificity and the sensitivity of the PCR assay were then determined by using these primers. As expected, a 558-bp band was detected after agarose gel electrophoresis of the PCR amplification products of all intestinal spirochete strains listed in Table 1. The lower limit of detection of intestinal spirochetes in the assay was approximately 20 bacteria (data not shown). No amplification products were detected with any non-Serpulina DNA except Brachyspira aalborgi DNA (data not shown).

After analyzing the rrs (16S rRNA gene) sequences in the databases, we found restriction sites for four enzymes to differentiate the Serpulina species. The 558-bp amplicon was further analyzed for restriction enzyme digestion products by using several strains of each species (Table 1). Four patterns were found for the five species of intestinal spirochetes; an example is shown in Fig. 1. HinfI differentiated S. innocens and $S$. murdochii from the other three species (Fig. 1A, lanes 3 and 5). While $S a u 3 A$ digestion gave a unique pattern for $S$. murdochii (Fig. 1B, lane 5), TaqI digestion yielded a distinguishing pattern for $S$. pilosicoli (type strain P43/6/78 and strains of human origin; Fig. $1 C$, lanes 6 to 15 ). $S$. intermedia could not be differentiated from $S$. hyodysenteriae by this RFLP-PCR assay, and this result could be related to the fact that the $r r s$ se-

TABLE 4. Metabolic end products of growing cells of S. murdochii $56-150^{\mathrm{T}}$ and $S$. intermedia $\mathrm{PSW} / \mathrm{A}^{\mathrm{T}}$

\begin{tabular}{lcc}
\hline \multirow{2}{*}{ Product $^{a}$} & \multicolumn{2}{c}{ Amt produced $(\mu \mathrm{mol} / \mathrm{ml} \text { of medium })^{b}$} \\
\cline { 2 - 3 } & $S$. murdochii $56-150^{\mathrm{T}}$ & $S$. intermedia PWS/A $^{\mathrm{T}}$ \\
\hline Acetate & 25.4 & 14.0 \\
Butyrate & 5.2 & 10.3 \\
Ethanol & 1.0 & 1.4 \\
$\mathrm{CO}_{2}$ & 14.8 & 7.2 \\
$\mathrm{H}_{2}$ & 33.0 & 10.7 \\
\hline
\end{tabular}

${ }^{a}$ The following compounds were assayed for but were not detected as products of either strain: formate, lactate, propionate, isobutyrate, valerate, succinate, butanol, and propanol.

${ }^{b}$ The culture medium used was HS broth supplemented with $0.4 \%$ glucose, and the initial culture atmosphere was $1 \% \mathrm{O}_{2}-99 \% \mathrm{~N}_{2}$. The oxygen in the culture atmospheres was completely consumed by both strains during growth, and the oxygen concentration was estimated to be $2 \mu \mathrm{mol} / \mathrm{ml}$ of culture broth. The gas yields were calculated as micromoles per milliliter and do not reflect the actual concentrations of gases in the medium. 
TABLE 5. Phenotypic characteristics of Serpulina species $^{a}$

\begin{tabular}{|c|c|c|c|c|c|c|c|}
\hline Species & Hemolysis & $\begin{array}{l}\text { Indole } \\
\text { production }\end{array}$ & $\begin{array}{l}\text { Hippurate } \\
\text { hydrolysis }\end{array}$ & $\begin{array}{l}\alpha \text {-Galactosidase } \\
\text { activity }\end{array}$ & $\begin{array}{c}\alpha \text {-Glucosidase } \\
\text { activity }\end{array}$ & $\begin{array}{c}\beta \text {-Glucosidase } \\
\text { activity }\end{array}$ & $\begin{array}{l}\text { No. of flagella } \\
\text { per cell }\end{array}$ \\
\hline S. hyodysenteriae & Strong & + & - & - & + & + & $22-28$ \\
\hline S. innocens & Weak & - & - & - & $+1-$ & + & $20-26$ \\
\hline S. pilosicoli & Weak & - & + & $+1-$ & $+1-$ & - & $8-12$ \\
\hline S. intermedia sp. nov. & Weak & + & - & - & + & + & $24-28$ \\
\hline S. murdochii sp. nov. & Weak & - & - & - & - & + & $22-26$ \\
\hline
\end{tabular}

${ }^{a}$ Phenotypic characteristics are based on results of tests performed in this study with $S$. intermedia $\mathrm{PWS} / \mathrm{A}^{\mathrm{T}}$ and 2818.5 and $S$. murdochii $56-150^{\mathrm{T}}$ and 155.20 and on results of previous studies $(7,8,11,23)$. The symbol $+/-$ indicates that some strains possess and other strains lack the particular enzymatic activity.

quences of these two species are very similar $(26,35)$. In addition, Brachyspira aalborgi could be differentiated from the Serpulina species since its amplicon was cleaved by $M b o$ II into two fragments that were 93 and 465 bp long (data not shown) and the amplicons from the Serpulina species were not cut by this enzyme.

\section{DISCUSSION}

The levels of DNA relatedness confirmed, as expected, the three previously delineated Serpulina species, $S$. hyodysenteriae, $S$. innocens, and $S$. pilosicoli (formerly called " $A$. coli"). Fur- thermore, DNA-DNA reassociation results also validated two new Serpulina species, consistent with conclusions based on MEE data $(19,20)$. For these new species we propose the names $S$. intermedia (previously called "S. intermedius") and S. murdochii (previously also called group B spirochetes) (19, 20). Indeed, DNA relatedness results indicate that the groups of intestinal spirochete strains defined previously on the basis of MEE results $(20,35)$ represent separate Serpulina species. Groups I, III, and VI correspond to $S$. hyodysenteriae, $S$. innocens, and $S$. pilosicoli, respectively, while group II corresponds to $S$. intermedia sp. nov. and group $\mathrm{V}$ corresponds to $S$. mur-

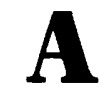

a 123456

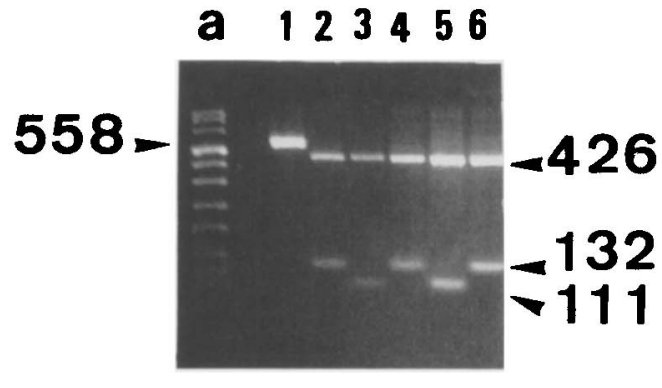

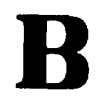

a 1223456

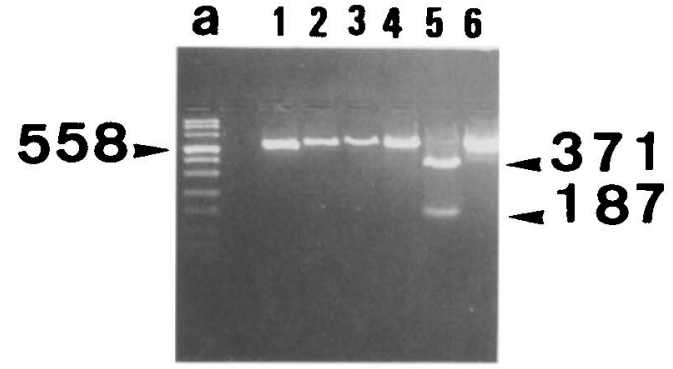

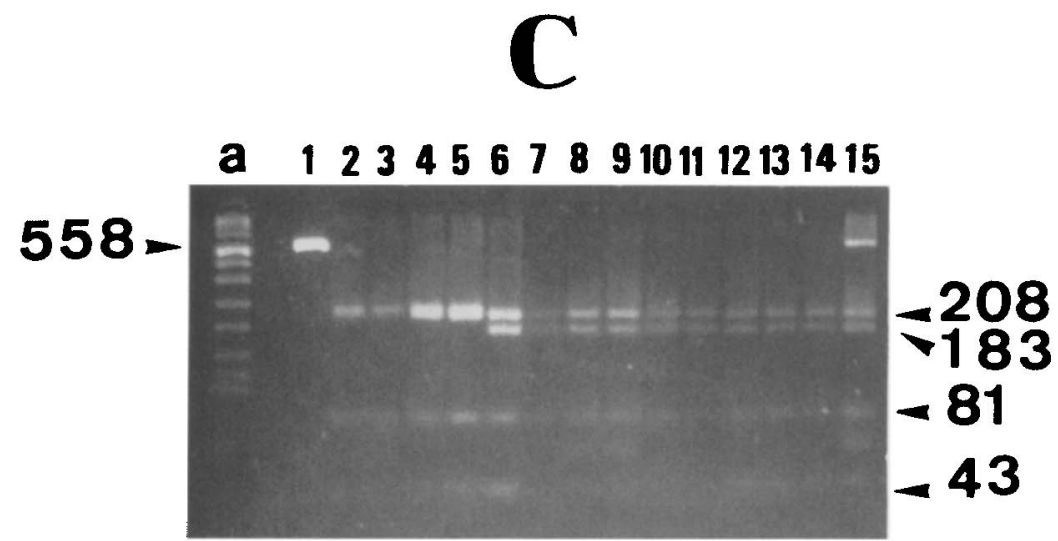

FIG. 1. RFLP-PCR analysis of Serpulina isolates. (A) HinfI digestion of the 558-bp PCR fragment distinguishing $S$. murdochii and $S$. innocens from the other species. Lane 1 , undigested fragment; lanes 2 to 6 , Hinfl digestion patterns for $S$. hyodysenteriae B $78^{\mathrm{T}}\left(=\mathrm{ATCC} 27164^{\mathrm{T}}\right), S$. innocens $\mathrm{B} 256^{\mathrm{T}}\left(=\mathrm{ATCC}^{\mathrm{T}} 29796^{\mathrm{T}}\right), S$. intermedia PWS $/ A^{\mathrm{T}}$ (= ATCC 51140 $)$, S. murdochii 56/150 ${ }^{\mathrm{T}}\left(=\right.$ ATCC $51254^{\mathrm{T}}$ ), and S. pilosicoli $\mathrm{P} 43 / 6 / 78^{\mathrm{T}}\left(=\right.$ ATCC $51139^{\mathrm{T}}$ ), respectively; lane a, type VIII molecular weight markers (Boehringer, Mannheim, Germany). (B) Sau3A digestion of the 558-bp PCR fragment distinguishing S. murdochii from the other species. Lane 1, undigested fragment; lanes 2 to 6, Sau3A digestion patterns for S. hyodysenteriae B78 ${ }^{\mathrm{T}}$ (= ATCC $\left.27164^{\mathrm{T}}\right)$, S. innocens B256 ${ }^{\mathrm{T}}\left(=\mathrm{ATCC} 29796^{\mathrm{T}}\right)$, S. intermedia PWS $/ \mathrm{A}^{\mathrm{T}}\left(=\mathrm{ATCC}^{\mathrm{A}}\right.$ $\left.51140^{\mathrm{T}}\right), S$. murdochii $56 / 150^{\mathrm{T}}\left(=\right.$ ATCC $\left.51254^{\mathrm{T}}\right)$, and $S$. pilosicoli $\mathrm{P} 43 / 6 / 78^{\mathrm{T}}\left(=\right.$ ATCC $\left.51139^{\mathrm{T}}\right)$, respectively; lane a, type VIII molecular weight markers $($ Boehringer). (C) TaqI digestion of the 558-bp PCR fragment distinguishing S. pilosicoli from the other species. Lane 1, undigested fragment; lanes 2 to 6 , TaqI digestion patterns for S. hyodysenteriae B78 ${ }^{\mathrm{T}}\left(=\mathrm{ATCC} 27164^{\mathrm{T}}\right)$, S. innocens $\mathrm{B} 256^{\mathrm{T}}$ (= ATCC $\left.29796^{\mathrm{T}}\right)$, S. intermedia PWS A $^{\mathrm{T}}\left(=\mathrm{ATCC} 51140^{\mathrm{T}}\right), S$. murdochii $56 / 150^{\mathrm{T}}\left(=\mathrm{ATCC} 51254^{\mathrm{T}}\right)$, and $S$. pilosicoli $\mathrm{P} 43 / 6 / 78^{\mathrm{T}}$ (= ATCC $51139^{\mathrm{T}}$ ), respectively; lanes 7 to 15 , TaqI digestion patterns for $S$. pilosicoli human isolates; lane a, type VIII molecular weight markers (Boehringer). 
dochii sp. nov. (Table 1). Thus, besides the strongly hemolytic organism $S$. hyodysenteriae, four weakly hemolytic species are found in the genus Serpulina. These species roughly correlate with the biochemical-16S rRNA groups devised by Fellström et al. $(7,8,26)$, with $S$. intermedia representing their group II spirochetes, $S$. innocens representing groups IIIb and IIIc, $S$. murdochii representing group IIIa, and $S$. pilosicoli representing group IV.

S. murdochii and $S$. intermedia cells are similar in ultrastructure to cells of $S$. hyodysenteriae. These two species share a number of phenotypic properties with other Serpulina species. All Serpulina species studied use soluble sugars as growth substrates. All five Serpulina species consume oxygen during growth beneath an atmosphere containing $1 \%$ oxygen. A common mechanism for oxygen metabolism by Serpulina species is likely to be the enzyme NADH oxidase, which is present in strains of $S$. hyodysenteriae, $S$. innocens, and $S$. pilosicoli and in S. intermedia PWS $/ \mathrm{A}^{\mathrm{T}}$ and $S$. murdochii $56-150^{\mathrm{T}}(15 \mathrm{a}, 32)$. Cells of the five Serpulina species produce more $\mathrm{H}_{2}$ than $\mathrm{CO}_{2}$. In $S$. hyodysenteriae, the disproportionate amount of $\mathrm{H}_{2}$ has been attributed to an unusual mechanism for NADH- ${ }^{+}$oxidation (32). It is likely that this pathway is present in other Serpulina species.

As additional Serpulina species are isolated and identified, there is a need for practical diagnostic tests to differentiate the species, especially the weakly hemolytic species, at least one of which (S. pilosicoli) is a demonstrated pathogen. A comparison of phenotypic properties used to identify Serpulina species is given in Table 5. $S$. intermedia sp. nov. and $S$. hyodysenteriae cannot be differentiated by phenotypic characteristics except for a difference in hemolysis (Table 5). S. hyodysenteriae and $S$. intermedia strains produce indole, while the majority of the strains of the three other species do not. Among the species which do not produce indole, hydrolysis of hippurate and lack of $\beta$-glucosidase activity allow identification of $S$. pilosicoli and the presence of $\alpha$-galactosidase activity allows $S$. innocens strains to be identified (Table 5). Thus, S. murdochii sp. nov., which lacks $\alpha$-galactosidase and $\alpha$-glucosidase activities, appears to be distinct from the other species $(7,20)$. However, the levels of relatedness between the DNAs of the two $S$. murdochii strains and the DNA of $S$. innocens B256 ${ }^{\mathrm{T}}$ are borderline (64 to $66 \%$ ) in terms of delineating species. Nevertheless, as different ways to distinguish each of these species (electrophoretic types obtained by MEE and PCR analysis followed by analysis of restriction polymorphism) are available, we propose that $S$. murdochii sp. nov. should be considered a separate species.

Several procedures have been described for identifying either $S$. hyodysenteriae (versus $S$. innocens) or S. pilosicoli $(6,12$, 25). Our PCR assay based on the sequence of the rDNA encoding 16S rRNA and the presence of restriction sites for HinfI, TaqI, and Sau3A allowed us to differentiate other Serpulina species, particularly S. murdochii (Fig. 1). S. intermedia could be distinguished from the other weakly hemolytic species by RFLP analysis of the $16 \mathrm{~S}$ rDNA amplicon with all three restriction enzymes.

Description of Serpulina intermedia sp. nov. Serpulina intermedia (in.ter.me'di.a. L. fem. adj. intermedia, in the middle, referring to the fact that the biochemical reactivities of this organism are intermediate between those characteristically possessed by $S$. hyodysenteriae and by $S$. innocens [20]). Also called "Serpulina intermedius" (20). Some intestinal spirochetes referred to as "Treponema hyodysenteriae biotype 2" or "intermediate type" may be $S$. intermedia strains (2).

$S$. intermedia strains have been isolated from swine, including swine with diarrhea $(7,11)$. Evidence of pathogenicity after experimental infection of pigs with pure cultures has been inconclusive $(15,24) . S$. intermedia strains have been isolated from commercial poultry flocks exhibiting diarrhea and reduced production (23).

$S$. intermedia morphology and motility are typical of spirochetes (order Spirochaetales). Helical cells are 0.35 to 0.45 by 7.5 to $10 \mu \mathrm{m}$, generally exhibit a regular coiling pattern, and have 24 to 28 periplasmic flagella per cell $(12$ to 14 inserted at each cell end). Cells growing beneath an $\mathrm{N}_{2}-\mathrm{O}_{2}$ (99:1) atmosphere in stirred BHIS broth have a population doubling time of 2 to $4 \mathrm{~h}$ and an optimum growth temperature of 39 to $42^{\circ} \mathrm{C}$ and reach population densities of approximately $10^{9}$ cells $/ \mathrm{ml}$. Colonies on Trypticase soy agar containing $10 \%$ defibrinated bovine blood are weakly hemolytic. The spirochete does not grow aerobically.

Substrates that support growth of $S$. intermedia $\mathrm{PWS} / \mathrm{A}^{\mathrm{T}}$ in HS broth containing $7 \%$ fetal calf serum include glucose, fructose, sucrose, $\mathrm{N}$-acetylglucosamine, pyruvate, L-fucose, trehalose, galactose, and maltose. Substrates that do not support growth are D-fucose, glucosamine, ribose, raffinose, rhamnose, and xylose. In $\mathrm{HS}$ broth containing glucose beneath an $\mathrm{N}_{2}-\mathrm{O}_{2}$ (99:1) atmosphere, growing cells consume oxygen and yield $\mathrm{H}_{2}$, $\mathrm{CO}_{2}$, acetate, butyrate, and ethanol. Hydrogen is produced in greater amounts than $\mathrm{CO}_{2}$. Strain $\mathrm{PWS} / \mathrm{A}^{\mathrm{T}}$ cells express $\mathrm{NADH}$ oxidase activity and contain the nox gene.

$S$. intermedia strains have been classified by MEE analysis (MEE group II [35]) and by biochemical tests (group II spirochetes $[7,8])$. This spirochete has DNA homology levels of 57, 45,28 , and $37 \%$ with $S$. hyodysenteriae $\mathrm{B} 78^{\mathrm{T}}, S$. innocens $\mathrm{B} 256^{\mathrm{T}}$, $S$. pilosicoli $\mathrm{P} 43 / 6 / 78^{\mathrm{T}}$, and $S$. murdochii $56-150^{\mathrm{T}}$, respectively. $S$. intermedia $\mathrm{PWS} / \mathrm{A}^{\mathrm{T}}$ can be differentiated from other weakly hemolytic intestinal spirochetes $(S$. innocens, $S$. pilosicoli, $S$. murdochii sp. nov.) by RFLP-PCR analysis of the $16 \mathrm{~S}$ rDNA by using the enzymes HinfI, Sau3A, and TaqI. The restriction patterns of the 558-bp amplicon of rrs contain 132- and 426-bp fragments (HinfI); 43-, 81-, 208-, and 226-bp fragments (TaqI); and uncut 558-bp fragment (Sau3A).

Gram reaction negative and chemoorganotrophic. Produces indole and does not hydrolyze hippurate. Aerotolerant and anaerobic. Cells lack $\alpha$-galactosidase and possess $\alpha$-glucosidase and $\beta$-glucosidase activities. The $\mathrm{G}+\mathrm{C}$ content of the DNA is $25 \mathrm{~mol} \%$. Strain PWS/A $\mathrm{A}^{\mathrm{T}}$ has all of the properties of the species and has been deposited in the American Type Culture Collection as strain ATCC $51140^{\mathrm{T}}$.

Description of Serpulina murdochii sp. nov. Serpulina murdochii (mur.do'chi.i. M.L. masc. gen. n. murdochii, of Murdoch, in recognition of work conducted at Murdoch University in Western Australia, where the type strain was identified). Previously called "group B spirochetes" or "S. murdochii" (19, 20). S. murdochii strains have been isolated from intestinal contents of healthy swine and rats (38). The spirochete is not considered a pathogen.

$S$. murdochii morphology and motility are typical of spirochetes (order Spirochaetales). Substrates that support growth of $S$. murdochii $56-150^{\mathrm{T}}$ in HS broth containing $10 \%$ fetal calf serum include glucose, fructose, sucrose, $N$-acetylglucosamine, pyruvate, L-fucose, cellobiose, trehalose, maltose, mannose, and lactose. Substrates that do not support growth are galactose, D-fucose, glucosamine, ribose, raffinose, rhamnose, and xylose. Additional ultrastructural, motility, and growth characteristics of this spirochete are essentially the same as those reported above for $S$. intermedia.

$S$. murdochii strains have been classified by MEE analysis (MEE group V [35]). Type strain 56-150 has DNA homology levels of $27,66,22$, and $24 \%$ with $S$. hyodysenteriae $\mathrm{B} 78^{\mathrm{T}}$, S. innocens $\mathrm{B} 256^{\mathrm{T}}, S$. pilosicoli $\mathrm{P} 43 / 6 / 78^{\mathrm{T}}$, and $S$. intermedia PWS $/ A^{\mathrm{T}}$, respectively. $S$. murdochii $56-150^{\mathrm{T}}$ can be differenti- 
ated from other Serpulina species ( $S$. hyodysenteriae, S. innocens, $S$. pilosicoli, $S$. murdochii sp. nov.) by RFLP-PCR analysis of the 16S rDNA gene by using the enzyme Sau3A. The HinfI and Sau3A restriction patterns of a 558-bp amplicon of $r r s$ contain three fragments $(426,111$, and $21 \mathrm{bp})$ and two fragments ( 371 and $187 \mathrm{bp}$ ), respectively.

Gram reaction negative and chemoorganotrophic. Does not produce indole and does not hydrolyze hippurate. Aerotolerant and anaerobic. Cells lack $\alpha$-galactosidase and $\alpha$-glucosidase activities and possess $\beta$-glucosidase activity. The $\mathrm{G}+\mathrm{C}$ content of the DNA is 27 mol\%. Strain $56-150^{\mathrm{T}}$ has all of the properties of the species and has been deposited in the American Type Culture Collection as strain ATCC $51254^{\mathrm{T}}$.

\section{ACKNOWLEDGMENTS}

Part of this study was supported by a grant from the Australian Pig Research and Development Corporation and the Pasteur Institute. We thank B. Salauze and J. Carré-Cavellier (France) for supplying blood cultures containing spirochetes and our colleagues at the Pasteur Institute for supplying DNAs of diverse bacteria.

\section{REFERENCES}

1. Barrett, S. P. 1990. Intestinal spirochaetes in a Gulf Arab population. Epidemiol. Infect. 104:261-266.

2. Binek, M., and Z. M. Szynkiewicz. 1984. Physiological properties and classification of strains of Treponema sp. isolated from pigs in Poland. Comp. Immunol. Microbiol. Infect. Dis. 7:141-148.

3. Brosius, J., M. L. Palmer, P. J. Kennedy, and H. F. Noller. 1978. Complete nucleotide sequence of a 16S ribosomal RNA gene from Escherichia coli. Proc. Natl. Acad. Sci. USA 75:4801-4805.

4. Crosa, J. H., D. J. Brenner, and S. Falkow, 1973. Use of a single-strandspecific nuclease for analysis of bacterial and plasmid deoxyribonucleic acid homo- and heteroduplexes. J. Bacteriol. 115:904-911.

5. Cwyk, W. M., and E. Canale-Parola, 1979. Treponema succinifaciens sp. nov., an anaerobic spirochete from the swine intestine. Arch. Microbiol. 122:231-239.

6. Elder, R. O., G. E. Duhamel, R. W. Schafer, M. R. Mathiesen, and M. Ramanathan. 1994. Rapid detection of Serpulina hyodysenteriae in diagnostic specimens by PCR. J. Clin. Microbiol. 32:1497-1502.

7. Fellström, C., and A. Gunnarsson. 1995. Phenotypic characterization of intestinal spirochaetes isolated from pigs. Res. Vet. Sci. 59:1-4.

8. Fellström, C., B. Petterssọn, M. Uhilen, A. Gunnarsson, and K. E. Johansson. 1995. Phylogeny of Serpulina based on sequence analyses of the 16S rRNA gene and comparison with a scheme involving biochemical classification. Res. Vet. Sci. 59:5-9.

9. Fournié-Amazouz, E., G. Baranton, J. P. Carlier, G. Chambreuil, F. Cohadon, P. Collin, A. Gougeon Jolivet, I. Hermès, C. Lemarie, and I. Saint Girons. 1995. Isolations of intestinal spirochaetes from the blood of human patients. J. Hosp. Infect. 30:160-162.

10. Grimont, P. A. D., M. Y. Popoff, F. Grimont, C. Coynault, and M. Lemelin. 1980. Reproducibility and correlation study of three deoxyribonucleic acid hybridization procedureș. Curr. Microbiol. 4:325-330.

11. Hampson, D. J., and D. J. Trott. 1995. Intestinal spirochaetal infections of pigs: an overview with an Australian perspective, p. 139-169. In Manipulating pig production V. Australasian Pig Science Association, Werribee, Victoria, Australia.

12. Harel, J., and C. Forget. 1995. DNA probe and polymerase chain reaction procedure for the specific detection of Serpulina hyodysenteriae. Mol. Cell. Probes 9:111-119.

13. Harris, D. L., R. D. Glock, C. R. Christensen, and J. M. Kinyon. 1972. Swine dysentery: inoculation of pigs with Treponema hyodysenteriae (new species) and reproduction of the disease. Vet. Med. Small Anim. Clin. 67:61-64.

14. Hovind-Hougen, K., A. Birch-Andersen, R. Henrik-Nielsen, M. Orholm, J. O. Pedersen, P. S. Teglbjærg, and E. H. Thaysen. 1982. Intestinal spirochetosis: morphological characterization and cultivation of the spirochete Brachyspira aalborgi gen. nov., sp. nov. J. Clin. Microbiol. 16:1127-1136.

15. Hudson, M. J., T. J. L. Alexander, and R. J. Lysons. 1976. Diagnosis of swine dysentery: spirochaetes which may be confused with Treponema hyodysenteriae. Vet. Rec. 99:498-500.

15a.Jensen, N. S. (National Animal Disease Center). Personal communication.

16. Jensen, N. S., T. A. Casey, and T. B. Stanton. 1990. Detection and identification of Treponema hyodysenteriae by using oligodeoxynucleotide probes complementary to 16S rRNA. J. Clin. Microbiol. 28:2717-2721.

17. Jensen, N. S., T. B. Stanton, and D. E. Swayne. 1996. Identification of the swine pathogen Serpulina hyodysenteriae in rheas (Rhea americana). Vet. Microbiol. 52:259-269.
18. Lee, J. I., and D. J. Hampson. 1992. Intestinal spirochaetes colonizing aborigines from communities in the remote north of Western Australia. Epidemiol. Infect. 109:133-141.

19. Lee, J. I., and D. J. Hampson. 1994. Genetic characterisation of intestinal spirochaetes and their association with disease. J. Med. Microbiol. 40:365-371.

20. Lee, J. I., D. J. Hampson, A. J. Lymbery, and S. J. Harders. 1993. The porcine intestinal spirochaetes: identification of new genetic groups. Vet. Microbiol. 34:273-285.

21. Lemcke, R. M., and M. R. Burrows. 1981. A comparative study of spirochaetes from the porcine alimentary tract. J. Hyg. 86:173-182.

22. Mandel, M., and J. Marmur. 1968. Use of ultraviolet absorbance-temperature profile for determining the guanine plus cytosine content of DNA. Methods Enzymol. 12:195-206.

23. McLaren, A. J., D. J. Trott, D. E. Swayne, S. L. Oxberry, and D. J. Hampson. 1997. Genetic and phenotypic characterization of intestinal spirochetes colonizing chickens and allocation of known pathogenic isolates to three distinct genetic groups. J. Clin. Microbiol. 35:412-417.

24. Mhoma, J. R. L., D. J. Hampson, and I. D. Robertson. 1992. A serological survey to establish the prevalence of infection with Treponema hyodysenteriae in Western Australia. Aust. Vet. J. 69:81-84.

25. Park, N. Y., C. Y. Chung, A. J. McLaren, R. F. Atyeo, and D. J. Hampson. 1995. Polymerase chain reaction for identification of human and porcine spirochaetes recovered from cases of intestinal spirochaetosis. FEMS Microbiol. Lett. 125:225-230.

26. Pettersson, B., C. Fellström, A. Andersson, M. Uhlén, A. Gunnarsson, and K.-E. Johansson. 1996. The phylogeny of intestinal spirochetes (Serpulina species) based on sequence analysis of the 16S rRNA gene. J. Bacteriol. 178:4189-4199.

27. Sagartz, J. E., D. E. Swayne, K. A. Eaton, J. R. Hayes, K. D. Amass, R. Wack, and L. Kramer. 1992. Necrotizing typhlocolitis associated with a spirochete in rheas (Rhea americana). Avian Dis. 36:282-289.

28. Sambrook, J., E. F. Fritsch, and T. Maniatis. 1989. Molecular cloning: a laboratory manual, 2nd ed. Cold Spring Harbor Laboratory, Cold Spring Harbor, N.Y.

29. Sanna, A., G. Dettori, A. M. Aglianò, G. Branca, R. Grillo, F. Leone, A. Rossi, and G. Parisi. 1984. Studies of treponemes isolated from human gastrointestinal tract. L'Igiene Moderna 81:959-973.

30. Smibert, R. M. 1984. Genus III. Treponema Schaudinn 1905 , $1728^{\text {AL }}$, p. $49-$ 57. In N. R. Krieg and J. G. Holt (ed.), Bergey's manual of systematic bacteriology, vol. 1. The Williams and Wilkins Co, Baltimore, Md.

31. Stanton, T. B. 1992. Proposal to change the genus designation Serpula to Serpulina gen. nov. containing the species Serpulina hyodysenteriae comb. nov. and Serpulina innocens comb. nov. Int. J. Syst. Bacteriol. 42:189-190.

32. Stanton, T. B. 1997. Physiology of ruminal and intestinal spirochaetes, p. 7. In D. J. Hampson and T. B. Stanton (ed.), Intestinal spirochaetes in domestic animals and humans. CAB International Press, Wallingford, England.

33. Stanton, T. B., N. S. Jensen, T. A. Casey, L. A. Tordoff, F. E. Dewhirst, and B. J. Paster. 1991. Reclassification of Treponema hyodysenteriae and Treponema innocens in a new genus, Serpula gen. nov., as Serpula hyodysenteriae comb. nov. and Serpula innocens comb. nov. Int. J. Syst. Bacteriol. 41:50-58.

34. Stanton, T. B., and D. F. Lebo. 1988. Treponema hyodysenteriae growth under various culture conditions. Vet. Microbiol. 18:177-190.

35. Stanton, T. B., D. J. Trott, J. I. Lee, A. J. McLaren, D. J. Hampson, B. J. Paster, and N. S. Jensen. 1996. Differentiation of intestinal spirochetes by multilocus enzyme electrophoresis analysis and 16S rRNA sequence comparisons. FEMS Microbiol. Lett. 136:181-186.

36. Taylor, D. J., J. R. Simmons, and H. M. Laird. 1980. Production of diarrhoea and dysentery in pigs by feeding pure cultures of a spirochaete differing from Treponema hyodysenteriae. Vet. Rec. 106:326-332.

37. Trott, D. J., C. R. Huxtable, and D. J. Hampson. 1996. Experimental infection of newly weaned pigs with human and porcine strains of Serpulina pilosicoli. Infect. Immun. 64:4648-4654.

38. Trott, D. J., R. F. Atyeo, J. I. Lee, D. E. Swayne, J. W. Stoutenburg, and D. J. Hampson. 1996. Genetic relatedness amongst intestinal spirochaetes isolated from rats and birds. Lett. Appl. Microbiol. 23:431-436.

39. Trott, D. J., N. S. Jensen, I. Saint Girons, S. L. Oxberry, T. B. Stanton, D. Lindquist, and D. J. Hampson. 1997. Identification and characterization of Serpulina pilosicoli isolates recovered from the blood of critically ill patients. J. Clin. Microbiol. 35:482-485.

40. Trott, D. J., T. B. Stanton, N. S. Jensen, G. E. Duhamel, J. L. Johnson, and D. J. Hampson. 1996. Serpulina pilosicoli sp. nov., the agent of porcine intestinal spirochetosis. Int. J. Syst. Bacteriol. 46:206-215.

41. Trott, D. J., T. B. Stanton, N. S. Jensen, and D. J. Hampson. 1996. Phenotypic characteristics of Serpulina pilosicoli, the agent of intestinal spirochaetosis. FEMS Microbiol. Lett. 142:209-214.

42. Wayne, L. G., D. J. Brenner, R. R. Colwell, P. A. D. Grimont, O. Kandler, M. I. Krichevsky, L. H. Moore, W. E. C. Moore, R. G. E. Murray, E. Stackebrandt, M. P. Starr, and H. G. Trüper. 1987. Report of the Ad Hoc Committee on Reconciliation of Approaches to Bacterial Systematics. Int. J. Syst. Bacteriol. 37:463-464. 